\title{
Kinetics, modeling and colorimetry of celery leaves dehydration by direct and mixed solar drying
}

\section{Cinéticas, modelado y colorimetría del deshidratado de hojas de apio mediante secado solar directo y mixto}

\author{
CASTILLO-TÉLLEZ, Beatriz ${ }^{1} \dagger$, CASTILLO-TÉLLEZ-Margarita ${ }^{2 *}$, MEJÍA-PÉREZ, Gerardo Alberto ${ }^{3}$ \\ and VEGA-GÓMEZ, Carlos Jesahel ${ }^{3}$
}

${ }^{1}$ Centro Universitario del Norte, Universidad de Guadalajara, Colotlán, Jal., 46200

${ }^{2}$ Facultad de Ingeniería, Universidad Autónoma de Campeche, Camp., 24085.

${ }^{3}$ Centro Universitario de Tonalá, Universidad de Guadalajara, Tonalá, Jal. 45425

ID $1^{\text {st }}$ Author: Beatriz, Castillo-Téllez, / ORC ID: 0000-0003-3747-6320, Researcher ID Thomson: S-2264-2018, CVU CONACYT ID: 210564

ID $1^{\text {st }}$ Co-author: Margarita Castillo-Téllez / ORC ID: 0000-0001-9639-1736, Researcher ID Thomson: S-2283-2018, CVU CONACYT ID: 210428

ID $2^{\text {nd }}$ Co-author: Gerardo Alberto, Mejía Pérez / ORC ID: 0000-0003-1701-1171

ID $3^{\text {rd }}$ Co-author: Carlos Jesahel, Vega Gómez, / ORC ID: 0000-0003-2561-7763

DOI: $10.35429 /$ JTIP.2021.13.5.22.28

Received March 30, 2021; Accepted June 30, 2021

Abstract

In celery, leaves, roots, and fruit contain a high value in medicinal properties and are used to prepare syrups, tinctures, infusions, or oils; however, its leaves are commonly discarded, wasting their nutritional and medicinal content. The dehydration of these leaves is a conservation option, increasing their shelf life. This study analyzes direct and mixed solar drying (SD and SM) kinetics and their effect on celery leaves. The moisture contents, drying rate, water activity, and colorimetry were obtained. Moreover, the fitting of experimental data to the mathematical models proposed in the literature. The moisture content stabilized at $150 \mathrm{~min}$ in the SM at the shortest time with a maximum drying rate of $0.1179 \mathrm{~g} \cdot$ water $/ \mathrm{g} \cdot \mathrm{dm} \cdot \mathrm{min}$. The initial and final water activity was 0.98 and 0.412 in the SM and 0.403 in the SD. The SD better conserved the leaf color, with a total color change $(\Delta \mathrm{E})$ of 2.56, while the value obtained with the SM was 5.42. The experimental results of both technologies were better adjusted to the model Two exponential terms with an $\mathrm{R}^{2}$ of 0.999 . The results show that the solar drying of the celery leaves is feasible, and a quality product is obtained sustainably.

Celery, Drying models, Direct solar dryer, Mixed solar dryer, Colorimetry, Drying kinetics

\begin{abstract}
Resumen
En el apio, tanto sus hojas, raíces y el fruto, contienen un alto valor en propiedades medicinales que son aprovechadas para la elaboración de jarabes, tinturas, infusiones o aceites; sin embargo, sus hojas, son comúnmente desechadas, desaprovechando su contenido nutrimental y medicinal. El deshidratado de estas hojas es una opción de conservación, aumentando su tiempo de vida en anaquel. En este estudio se analizan las cinéticas en un secador directo y mixto (SD y SM) y su efecto en las hojas de apio. Se obtuvieron los contenidos de humedad, velocidad de secado, actividad del agua y colorimetría, así como los ajustes de los datos experimentales a los modelos matemáticos propuestos en literatura. El contenido de humedad se estabilizó a los 150 min en el SM, siendo este el menor tiempo con velocidad de secado máxima de $0.1179 \mathrm{~g} \cdot$ agua $/ \mathrm{g} \cdot \mathrm{ss} \cdot \mathrm{min}$. La actividad del agua inicial fue 0.98 y final de 0.412 en el SM y 0.403 en el SD. El SD conservó mejor el color de la hoja, con un cambio de color total $(\Delta \mathrm{E})$ de 2.56 , mientras que el valor obtenido con el SM fue de 5.42. Los resultados experimentales de ambas tecnologías se ajustaron de mejor manera al modelo Dos términos exponenciales con un $\mathrm{R}^{2}$ de 0.999 . Los resultados muestran que el secado solar de las hojas de apio es factible y se obtiene un producto de calidad, de manera sustentable.
\end{abstract}

Apio, Modelos de secado, Secador solar directo, Secador solar mixto, Colorimetría, Cinéticas de secado

Citation: CASTILLO-TÉLLEZ, Beatriz, CASTILLO-TÉLLEZ-Margarita, MEJÍA-PÉREZ, Gerardo Alberto and VEGAGÓMEZ, Carlos Jesahel. Kinetics, modeling and colorimetry of celery leaves dehydration by direct and mixed solar drying. Journal of Technologies in Industrial Processes. 2021. 5-13: 22-28

\footnotetext{
* Author Correspondence (mcastill@uacam.mx)

$\dagger$ Researcher contributing as first author.
} 


\section{Introduction}

The fruits and stems of the celery type Apium graveolens $L$. are a resource used for their high essential oils, linoleic acids, etc. Consumers mostly discard celery leaves. However, these leaves contain alkaloids, flavonoids, tannins, steroids, triterpenoids, and lactones, which can be used in snacks, seasonings, and medicinal uses. (Dasilveira, 2002).

Currently, methods of celery preservation include minimally processed vacuum impregnation for vitamin E preservation (Castaño et al., 2011), using matrix engineering allowing the extraction of extracellular gases and liquids allowing the entry of dispersions, solutions, or emulsions of food (Fito et al., 2001). The traditional method of preserving celery is cooling temperatures around $0^{\circ}$ to $3^{\circ} \mathrm{C}$, with a humidity of 95 to $98 \%$, avoiding dehydration and obtaining four months in conservation (Reina G. et al., 1996). Studies and dehydration of celery leaves are very little or no. Food dehydration uses equipment that usually works on gas, electrical energy, and in a few cases by solar panels (Romero et al., 2016), generating an environmental footprint.

An alternative is solar dryers: indirect, mixed and direct. Indirect dryers prevent the crystallization of sugars and exposure damage, because the product is placed inside darker chambers, increasing the temperature of the air circulating through solar heaters. This method preserves the vitamin content and color of the product. The direct method is done by placing the product inside a shelf, with a transparent top cover taking advantage of the filtration of solar rays, extracting the humidity of the product and the relative humidity of the air through holes. The SM is a combination of indirect and direct dryers (Isaac Pilatowsky, 2013) commonly the hot air is made by means of a solar collector, heating the air, towards the cabinet with a transparent top cover, the hot air circulates through the cabinet and escaping through a chimney.

Very few studies dried of celery leaves are found in literature, such as that carried out in stove by convection with hot air, at three temperatures $\left(35^{\circ}, 45^{\circ}\right.$ y $55^{\circ} \mathrm{C}$ ) (Vicencio Pérez, 2016). Other research conducted on conventional dryers $35^{\circ} \mathrm{C}$, where the drying of one $\mathrm{kg}$ of celery leaf is reported producing 170 grams of dry leaf (Najda et al., 2015).
A quality parameter in food drying is color, occupying the first place among other sensory aspects such as smell, texture, taste, and finally, the sound when chewed (Hernandez, 2005). In this work, the drying of celery leaves type Apium graveolens L. was performed using an SD cabinet type with a time of 3 hours and a mixed solar dryer with a time of 150 minutes. In addition, drying kinetics, adjustment to mathematical models, and a colorimetric study are presented to determine the most appropriate solar technology.

\section{Materials and Methods}

\section{Raw material}

The celery leaves were acquired in Xochitepec, Morelos, Mexico, located in the northwestern part of the State. The study was carried out in September 2020 in the facilities of Modulo Solar, located in the Science and Technology Park of Morelos. The leaves were selected to obtain homogeneous samples based on size, color, and similar weight. The experiment was carried out in triplicate, and the present results are its average.

\section{Solar equipment used}

The 35 X 64 X $26 \mathrm{~cm}$ cabinet-type dryer, made of transparent polycarbonate with an area of .30 $\mathrm{m}^{2}$, shown in Figure 1, has perforations on the sides, bottom, and back for air circulation. The top cover has a slope of $20^{\circ}$ for the use of solar radiation. This type of dryer is easily accessible and low cost for its materials. In addition, the dryer requires minimal maintenance and protects food from dust, rain, and rodents or insects.

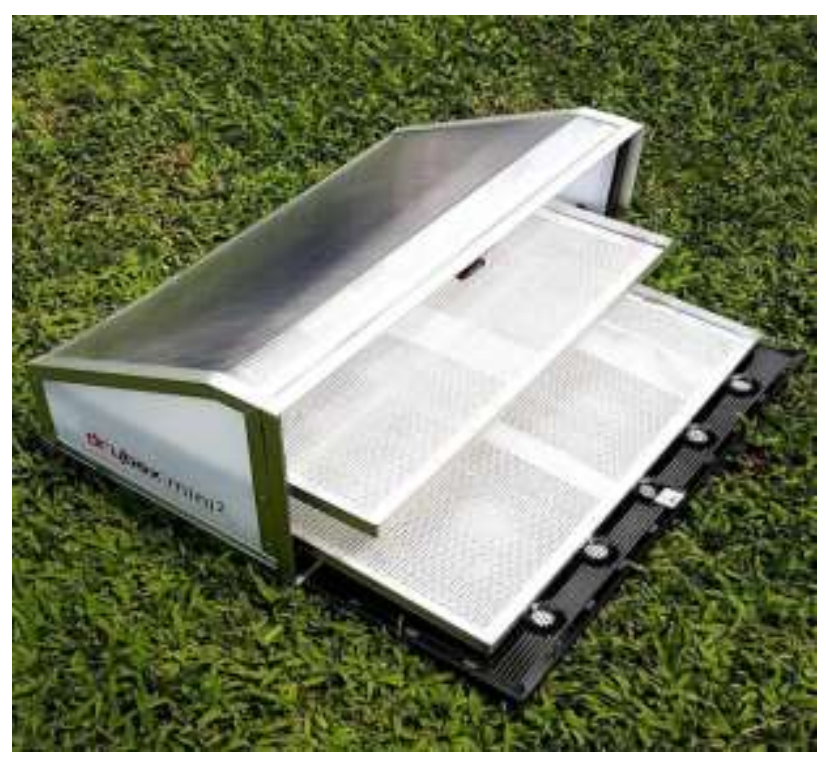

Figure 1 Direct solar dryer

CASTILLO-TÉLLEZ, Beatriz， CASTILLO-TÉLLEZ-Margarita, MEJÍA-PÉREZ, Gerardo Alberto and VEGA-GÓMEZ, Carlos Jesahel. Kinetics, modeling and colorimetry of celery leaves dehydration by direct and mixed solar drying. Journal of Technologies in Industrial Processes. 2021 
The SM is observed in Figure 2. It is equipped with a solar air collector with an inclination of $26^{\circ}$, incorporated into a drying chamber with a transparent polycarbonate top cover of $27^{\circ}$, employing an air duct. The air extraction is carried out by a chimney coupled to the drying chamber in the upper-rear part, allowing the extraction of moist and hot air. The chamber's back has a hinged door for the sample's introduction; inside the room, there are six drying trays, two at the top, two in the center, and two at the bottom of the chamber.

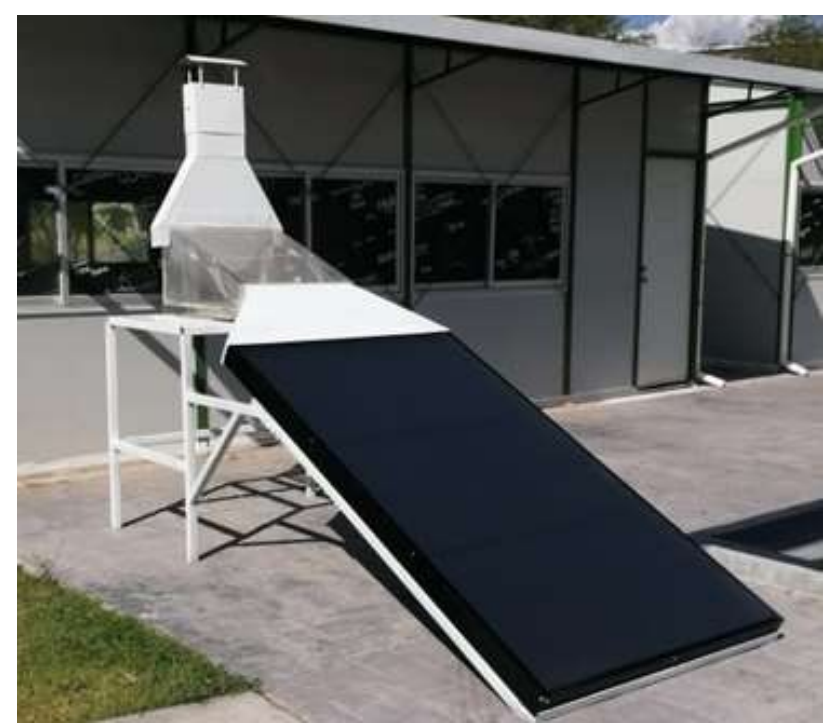

Figure 2 Mixed solar dryer

The $20 \mathrm{~g}$ samples were placed in the direct cabinet dryers and in the SM. These samples were placed in a dispersed way in meshes of $20 \times 10 \mathrm{~cm}$. Studies were conducted before and after drying of: colorimetry, water activity and moisture content and subsequently the weight loss of the samples was followed up every 15 minutes. All experiments were conducted in triplicate. The measuring equipment used is shown in the Table 1.

\section{Instrumentation}

\begin{tabular}{|c|c|c|c|}
\hline Instrument & Quantity & Brand/Type & Characteristics \\
\hline $\begin{array}{l}\text { Moisture } \\
\text { analyzer }\end{array}$ & 1 & $\begin{array}{l}\text { Boeco model } \\
\text { BMA } 150 .\end{array}$ & $\begin{array}{l}\text { Accuracy of } \\
\pm 0.01 \% \mathrm{mg} .\end{array}$ \\
\hline Hygrometer & 1 & $\begin{array}{l}\text { Rotronic } \\
\text { HygroPalm AW1 }\end{array}$ & $\begin{array}{l}\text { Accuracy } 0,005 \\
a_{w}+1,5 \% \text { de } \\
\text { lecture. Range } 0 \\
-1.000 \mathrm{a}_{\mathrm{w}} \text {. } \\
\end{array}$ \\
\hline Colorimeter & 1 & $\begin{array}{l}\text { 3NH NR145 } \\
\text { Brand: } \\
\text { JIAWANSHUN. }\end{array}$ & $\begin{array}{l}\text { Errors between } \\
\text { each media: } \leq \\
0,80 \delta \mathrm{e}^{*} \mathrm{ab} .\end{array}$ \\
\hline Digital scale & 1 & $\begin{array}{l}\text { Rhino BABOL- } \\
\text { 100G }\end{array}$ & 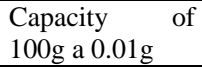 \\
\hline $\begin{array}{l}\text { Temperature } \\
\text { and humidity } \\
\text { sensor }\end{array}$ & 2 & $\begin{array}{l}\text { Inkbird/IBS- } \\
\text { TH1. }\end{array}$ & $\begin{array}{l} \pm 2 \% \text { RH y } \pm 0.5 \\
{ }^{\circ} \mathrm{C} .\end{array}$ \\
\hline
\end{tabular}

Table 1 Instrumentation for measurement

\section{Thin layer models}

Table 2 shows the mathematical models to which the kinetics of the drying of the Quelite were adjusted. The function for calculating the humidity ratio (MR) is shown in equation 1 (Toĝrul \& Pehlivan, 2004a). The MR humidity radius is a function of the drying time and is calculated as in (Toĝrul \& Pehlivan, 2004b):

$M R=\frac{M_{c}-M_{e}}{M_{0}-M_{e}}$

$\mathrm{M}_{\mathrm{c}}$ is the moisture content, $\mathrm{M}_{\mathrm{e}}$ is the equilibrium humidity, and $\mathrm{M}_{\mathrm{o}}$ is the initial humidity.

Statistical methods of regression and correlation were used for modeling. These statistical analyses were calculated using the DataFit 9.1 software.

Coefficient of determination was used $\left(\mathrm{R}^{2}\right)$ as the primary criterion for selecting the improvement model to fit the experimental data. Additionally, the reduced chi-square was calculated, $\chi^{2}$, and the analysis of the mean squared error, RMSE. Thus, the best fit of the data is the one with the most $\mathrm{R}^{2}$ and the minor $\chi^{2}$ and RMSE.

\begin{tabular}{|l|l|l|}
\hline \multicolumn{1}{|c|}{ Model Name } & \multicolumn{1}{c|}{ Model Reference } \\
\hline Newton & $M R=\exp (-k t)$ & $\begin{array}{l}\text { (Liu \& Bakker- } \\
\text { Arkema, 1997) }\end{array}$ \\
\hline Page & $M R=\exp \left(-k t^{n}\right)$ & (Page, 1949) \\
\hline $\begin{array}{l}\text { Modified } \\
\text { Page }\end{array}$ & $M R=\exp \left(-(k t)^{n}\right)$ & $\begin{array}{l}\text { (White et al., } \\
1981)\end{array}$ \\
\hline $\begin{array}{l}\text { Henderson } \\
\text { and Pabis }\end{array}$ & $M R=a \exp (-k t)$ & $\begin{array}{l}\text { (Henderson \& } \\
\text { Pabis, 1961) }\end{array}$ \\
\hline Logarithmic & $\begin{array}{l}M R=a \exp (-k t)+ \\
(\text { Toğrul, 2005) }\end{array}$ \\
\hline Two-term & $\begin{array}{l}M R=a \exp \left(-k_{0} t\right)+ \\
b \exp \left(-k_{1} t\right)\end{array}$ & $\begin{array}{l}\text { (Henderson, } \\
1974)\end{array}$ \\
\hline $\begin{array}{l}\text { Two-term } \\
\text { exponential }\end{array}$ & $\begin{array}{l}\text { (Y. I. Sharaf- } \\
=a \exp (-k t)+(1 \\
-a) \exp (-k a t)\end{array}$ & $\begin{array}{l}\text { Eldeen et al., } \\
1980)\end{array}$ \\
\hline $\begin{array}{l}\text { Wang and } \\
\text { Singh }\end{array}$ & $M R=1+a t+b t^{2}$ & $\begin{array}{l}\text { (Wang \& Singh, } \\
1978)\end{array}$ \\
\hline Weibull & $M R=\exp (-t / \beta)^{\alpha}$ & $\begin{array}{l}\text { (Tzempelikos et } \\
\text { al., 2015) }\end{array}$ \\
\hline
\end{tabular}

Table 2 Thin layer models based on moisture radius applied to drying kinetics

\section{Colorimetry}

The color parameter was determined by reflectance and was expressed in terms of the parameters $\mathrm{L}^{*}$ (whiteness-dark), a* (rednessgreenness), $\mathrm{b}^{*}$ (yellow-bluish), $\mathrm{H}^{*}$ (tone angle) property of color, and saturation or intensity $\mathrm{C}^{*}$ (Chroma). Additionally, the total color change $\Delta \mathrm{E}$ was calculated.

CASTILLO-TÉLLEZ, Beatriz, CASTILLO-TÉLLEZ-Margarita, MEJÍA-PÉREZ, Gerardo Alberto and VEGA-GÓMEZ, Carlos Jesahel. Kinetics, modeling and colorimetry of celery leaves dehydration by direct and mixed solar drying. Journal of Technologies in Industrial Processes. 2021 


\section{Results and Discussion}

Figure 3 shows the climatological data of irradiation and ambient temperature on a typical day of experimentation. The maximum irradiance reached $940 \mathrm{~W} / \mathrm{m}^{2}$ and the maximum temperatures $30{ }^{\circ} \mathrm{C}$.

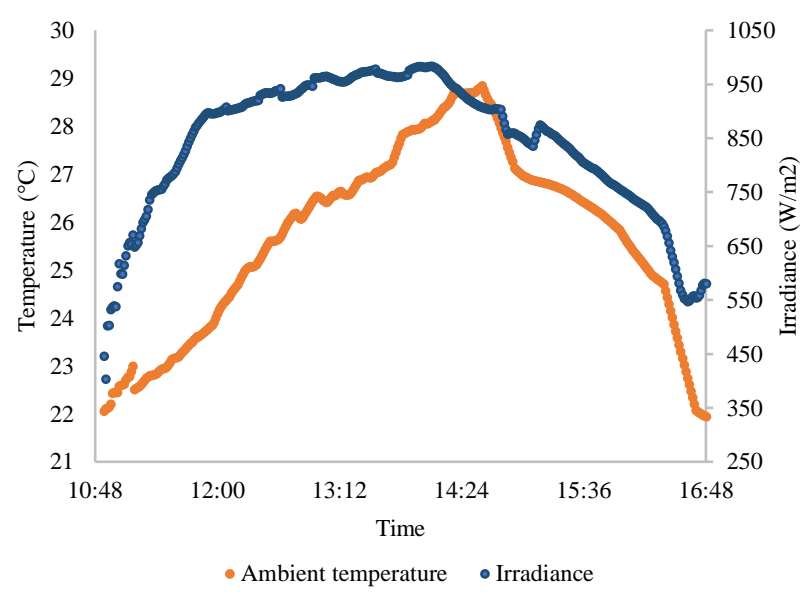

Figura 3 Evolution of climatological parameters

In Figure 4, the maximum temperatures and humidity reached by the dryers were 75.6 ${ }^{\circ} \mathrm{C}, 59.36 \mathrm{RH}(\%)$ for the SM and $46.1^{\circ} \mathrm{C}, 77.25$ $\mathrm{RH}(\%)$ for the SD dryer.

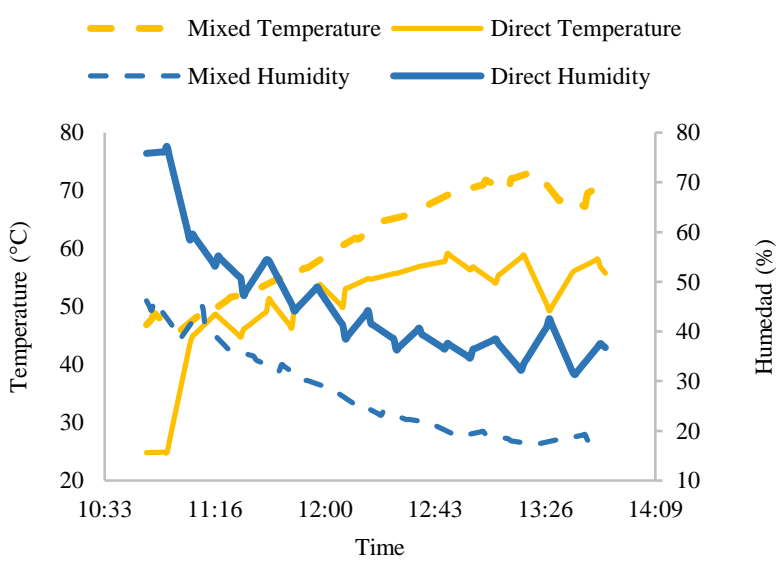

Figure 4 Humidity and temperatures in solar dryers

Figure 4 compares the temperatures and humidity of the two types of dryers. A higher temperature and lower humidity are seen in the SM compared to the SD dryer.

The drying time to reach the food's equilibrium moisture decreases when the temperature increases and when the humidity decreases, which can be seen in Figure 5. In the SM, which reached much higher temperatures and lower humidity inside the chamber, the drying was completed in 150 minutes.
On the contrary, in the SD, 180 minutes were needed. However, it can be observed that, with the SD, the final moisture content has a higher value than that achieved with the mixed.

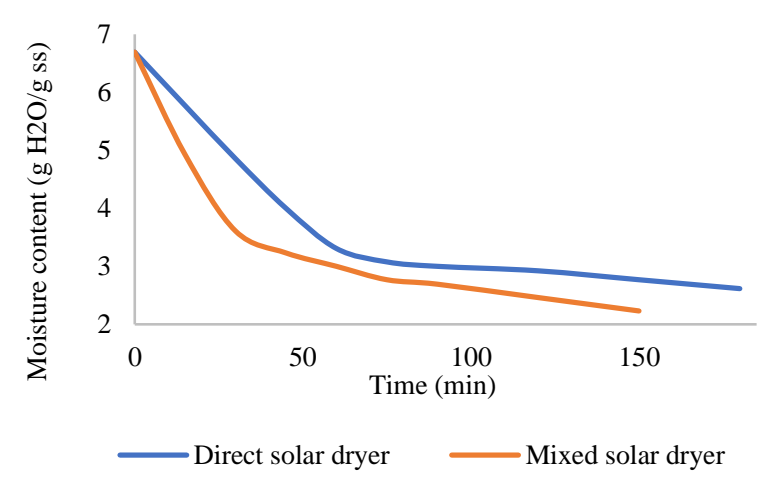

Figure 5 Moisture content loss during drying

The final drying rates in both dryers are shown in Figure 7 . The drying rate is higher in the mixed solar dryer due to the higher temperature, $0.12 \mathrm{~g} \mathrm{H}_{2} \mathrm{O} / \mathrm{g}$ ss min, with a moisture content of $6.69 \mathrm{~g} \mathrm{H}_{2} \mathrm{O} / \mathrm{g}$ ss.

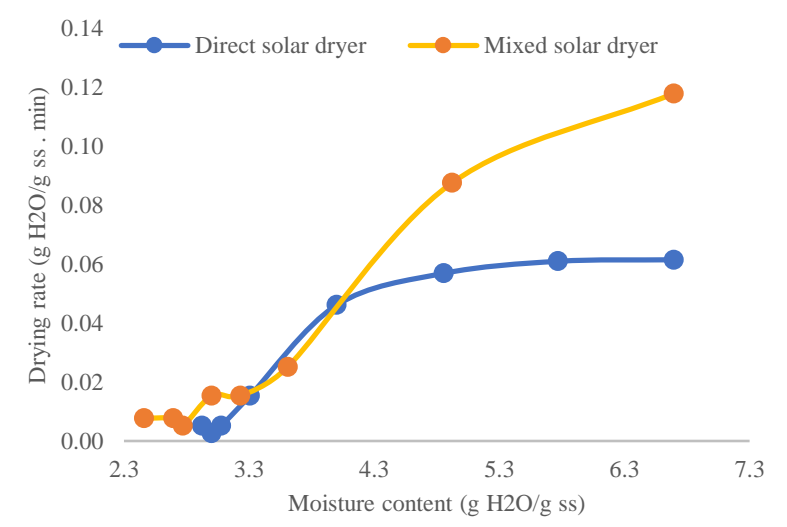

Figure 6 Drying rate in both technologies

Table 3 shows the water activity and moisture content in both samples; it is guaranteed that the product has the conditions to prevent the spread of agents that deteriorate the product in the short term.

\begin{tabular}{|l|r|r|r|r|}
\hline \multirow{2}{*}{$\begin{array}{c}\text { Technology } \\
\text { used }\end{array}$} & \multicolumn{2}{c}{ Water activity (Aw) } & \multicolumn{2}{c|}{ Humidity (\%) } \\
Initial & \multicolumn{1}{c|}{ Final } & \multicolumn{1}{c|}{ Initial } & \multicolumn{1}{c|}{ Final } \\
\hline Direct solar & 0.98 & 0.403 & 87 & 9.6 \\
\hline SM & 0.98 & 0.412 & 87 & 5.7 \\
\hline
\end{tabular}

Table 1 Water activity $\left(\mathrm{A}_{\mathrm{w}}\right)$ y humidity $(\%)$ initials and endings

Short drying times are desirable because a greater volume of product can dry in less time. However, very high temperatures usually decrease the quality of the food, deteriorating the color of the leaves, which indicates the loss of some nutrients.

CASTILLO-TÉLLEZ, Beatriz, CASTILLO-TÉLLEZ-Margarita, MEJÍA-PÉREZ, Gerardo Alberto and VEGA-GÓMEZ, Carlos Jesahel. Kinetics, modeling and colorimetry of celery leaves dehydration by direct and mixed solar drying. Journal of Technologies in Industrial Processes. 2021 
Table 4, showing the final color differences concerning the dryers, had as a final result the sum of squares of 2,561 for the SD dryer and 5,423 for the SM. Thus, although temperatures were very high in the SM and direct radiation affected the color of the leaf, the color change is acceptable, compared to results reported in (Ali et al., 2014; Castillo Téllez et al., 2018). In the literature, it has been reported that there is a notable difference in color when the values are between 2 to 12 units (Hii et al., 2006). The International Commission on Illumination states that values between 0 and 2 in color difference are unrecognizable to the human eye, but any observer can easily identify values above five. (Zielinska \& Markowski, 2012).

\begin{tabular}{|l|r|r|r|}
\hline Color space & \multicolumn{1}{r|}{ Initial } & Final-Cabinet & Final-Mixed \\
\hline L & 32.65 & 32.37 & 37.43 \\
\hline a & 6.5 & 4 & 5.03 \\
\hline b & 13.2 & 13.68 & 15.3 \\
\hline c & 14.72 & 14.32 & 16.33 \\
\hline h & 63.8 & 74.23 & 72.02 \\
\hline
\end{tabular}

Table 2 Color change in both experiments

\section{Mathematical Models}

Tables 5 and 6 show the mathematical models that best fit the SD and SM dryers. As you can see, the behavior of the data of the celery sheets during drying, is largely adjusted $(\mathrm{R}>0.95)$ to all the models analyzed. The model with the best fit for both dryers is the Weibull, so this model can be used for future predictions or dryer design.

\begin{tabular}{|c|c|c|}
\hline Model & Parameter & Value \\
\hline \multirow[t]{6}{*}{ Logarithmic } & $\mathrm{a}$ & 0.59459 \\
\hline & $\mathrm{c}$ & 0.41308 \\
\hline & $\mathrm{k}$ & 2.20472 \\
\hline & $\mathrm{R}^{2}$ & 0.99253 \\
\hline & RMSE & 0.01727 \\
\hline & $X^{2}$ & 0.000426 \\
\hline Model & Parameter & Value \\
\hline \multirow[t]{5}{*}{ Modified Page } & $\mathrm{k}$ & 0.383166 \\
\hline & $\mathrm{n}$ & 0.484135 \\
\hline & $\mathrm{R}^{2}$ & 0.954051 \\
\hline & RMSE & 0.042893 \\
\hline & $\mathrm{X}^{2}$ & 0.002299 \\
\hline Model & Parameter & Value \\
\hline \multirow[t]{7}{*}{ Weibull } & $\mathrm{a}$ & 0.41445 \\
\hline & $\mathrm{b}$ & -0.59233 \\
\hline & $\mathrm{k}$ & 2.24372 \\
\hline & $\mathrm{n}$ & 1.01576 \\
\hline & $\mathrm{R}^{2}$ & 0.99255 \\
\hline & RMSE & 0.01725 \\
\hline & $X^{2}$ & 0.00049 \\
\hline
\end{tabular}

Table 5 Direct solar dryer data adjustment to thin-film mathematical models

\begin{tabular}{|c|c|c|}
\hline Model & Parameter & Value \\
\hline \multirow[t]{5}{*}{ Page } & $\mathrm{k}$ & 0.825436 \\
\hline & $\mathrm{n}$ & 0.35766 \\
\hline & $\mathrm{R}^{2}$ & 0.954331 \\
\hline & RMSE & 0.043773 \\
\hline & $X^{2}$ & 0.002395 \\
\hline Model & Parameter & Value \\
\hline \multirow[t]{5}{*}{ Modified Page } & $\mathrm{k}$ & 0.58486 \\
\hline & $\mathrm{n}$ & 0.35766 \\
\hline & $\mathrm{R}^{2}$ & 0.954331 \\
\hline & RMSE & 0.043773 \\
\hline & $\mathrm{X}^{2}$ & 0.002395 \\
\hline Model & Parameter & Value \\
\hline \multirow[t]{7}{*}{ Weibull } & $\mathrm{a}$ & 0.12265 \\
\hline & $\mathrm{b}$ & 0.88029 \\
\hline & $\mathrm{k}$ & 1.03748 \\
\hline & $\mathrm{n}$ & 0.39546 \\
\hline & $\mathrm{R}^{2}$ & 0.95453 \\
\hline & RMSE & 0.04367 \\
\hline & $\mathrm{X}^{2}$ & 0.00317 \\
\hline
\end{tabular}

Tabla 6 Ajuste de datos del secador solar mixto a los modelos matemáticos de capa delgada

\section{Conclusions}

The dryer that best preserved the color of the sheet was the SD dryer because the temperature it reached was very high. The SM maintains a higher temperature and humidity inside the lower drying chamber than the cabinet type dryer; consequently, the drying rate is higher in this dryer. The best mathematical model that fits both experimental results (mixed and direct) is the Weibull.

\section{Reference}

Ali, M. A., Yusof, Y. A., Chin, N. L., Ibrahim, M. N., \& Basra, S. M. A. (2014). Drying Kinetics and Colour Analysis of Moringa Oleifera Leaves. Agriculture and Agricultural Science Procedia, 2, 394-400. https://doi.org/10.1016/j.aaspro.2014.11.055

Castaño, Y. J. M., Rodríguez, M. C., \& Mahecha, H. S. (2011). Desarrollo de apio mínimamente procesado fortificado con vitamina $\mathrm{E}$, utilizando la ingeniería de matrices. DYNA, 78(165), 28-39.

Castillo Téllez, M., Pilatowsky Figueroa, I., Castillo Téllez, B., López Vidaña, E. C., \& López Ortiz, A. (2018). Solar drying of Stevia (Rebaudiana Bertoni) leaves using direct and indirect technologies. Solar Energy, 159, 898907.

https://doi.org/10.1016/j.solener.2017.11.031 
Dasilveira, R. (2002). Vademecum colombiano de plantas medicinales. Ministerio de la protección social. Mycological Research, 106(11), 35-36.

Fito, P., Chiralt, A., Betoret, N., Gras, M., Cháfer, M., Martínez-Monzó, J., Andrés, A., \& Vidal, D. (2001). Vacuum impregnation and osmotic dehydration in matrix engineering: Application in functional fresh food development. Journal of Food Engineering, 49(2), $175-183$. https://doi.org/https://doi.org/10.1016/S02608774(00)00220-X

Henderson, S. M. (1974). Progress in developing the thin layer drying equation. Transactions of the American Society of Agricultural Engineers, $17(6)$.

Henderson, S. M., \& Pabis, S. (1961). Grain drying theory II: Temperature effects on drying coefficients. Journal of Agricultural Engineering Research, 6(3), 169-174.

Hernandez, E. (2005). EVALUACION SENSORIAL.

Hii, C. L., Rahman, R. A., Jinap, S., \& YB Che, M. (2006). Quality of cocoa beans dried using a direct solar dryer at different loadings. Journal of the Science of Food and Agriculture, 86(February 2006), 1237-1243. https://doi.org/10.1002/jsfa

Isaac Pilatowsky, J. T. Y. R. (2013). Secador solar de alimentos (Primera). Terracota.

Liu, Q., \& Bakker-Arkema, F. W. (1997). Stochastic modelling of grain drying: Part 2. Model development. Journal of Agricultural and Engineering Research, 66(4), 275-280. https://doi.org/10.1006/jaer.1996.0145

Najda, A. B., Dyduch, J., Sachadyn-Król, M., Najda, A., Świca, K., Kapłan, M., Papliński, R., \& Klimek, K. (2015). Identification and Profile of Furanocoumarins from the Ribbed Celery (Apium Graveolens L. Var. 2 Dulce Mill./ Pers.) Article in Food Science and Technology Research. Food Science and Technology Research, 21(1), 67-75. https://doi.org/10.3136/fstr.21.67
Page, G. E. (1949). Factors influencing the maximum rates of air drying shelled corn in thin layers. M. S. Thesis. Purdue University, West Lafayette, IN, USA.

Reina G., C. E., Cuenca Perdomo, J. I., \& Ortega Ospina, F. (1996). Manejo postcosecha y evaluación de la calidad para la cebolla junca (Allium Fistulosum) y el apio (Apium graveolens) que se comercializa en la ciudad de Neiva. Universidad Surcolombiana.

Romero, I., Díaz, V., \& Aguirre, A. (2016). Fortalecimiento de la cadena de valor de los snacks nutritivos con base en fruta deshidratada en El Salvador. Cepal, 1-114.

Toğrul, H. (2005). Simple modeling of infrared drying of fresh apple slices. Journal of Food Engineering, 71(3), 311-323. https://doi.org/10.1016/j.jfoodeng.2005.03.031

Toĝrul, I. T., \& Pehlivan, D. (2004a). Modelling of thin layer drying kinetics of some fruits under open-air sun drying process. Journal of Food Engineering, 65(3), 413-425. https://doi.org/10.1016/j.jfoodeng.2004.02.001

Toĝrul, I. T., \& Pehlivan, D. (2004b). Modelling of thin layer drying kinetics of some fruits under open-air sun drying process. Journal of Food Engineering, 65(3), 413-425. https://doi.org/10.1016/j.jfoodeng.2004.02.001

Tzempelikos, D. A., Vouros, A. P., Bardakas, A. V., Filios, A. E., \& Margaris, D. P. (2015). Experimental study on convective drying of quince slices and evaluation of thin-layer drying models. Engineering in Agriculture, Environment and Food, 8(3), 169-177. https://doi.org/10.1016/j.eaef.2014.12.002

\section{Vicencio Pérez, B. J. (2016). EVALUACIÓN DE LA CAPACIDAD ANTIOXIDANTE, CONTENIDO DE PIGMENTOS Y ESTUDIO DE CINÉTICA DE SECADO DE DESCARTES DE HOJA DE APIO (Apium graveolens L. var. dulce). Universidad de Chile.}

Wang, C. Y., \& Singh, R. P. (1978). A single layer drying equation for rough rice. American Society of Agricultural Engineers, 78, 3001. https://doi.org/10.1081/E-EEE2-120046011 
White, G. M., Ross, I. J., \& Poneleit, C. G. (1981). Fully-exposed drying of popcorn. European Physical Education Review, 24(2), 466-468,

https://doi.org/http://dx.doi.org/10.1108/175062 00710779521

Y. I. Sharaf-Eldeen, J. L. Blaisdell, \& M. Y. Hamdy. (1980). A Model for Ear Corn Drying. Transactions of the ASAE, 23(5), 1261-1265. https://doi.org/10.13031/2013.34757

Zielinska, M., \& Markowski, M. (2012). Color characteristics of carrots: Effect of drying and rehydration. International Journal of Food Properties, 15(2), 450-466. https://doi.org/10.1080/10942912.2010.489209 